Studies in African Linguistics

Volume 23, Number 2, 1992-1994

\title{
EPENTHESIS, MUTATION, AND STRUCTURE PRESERVATION IN THE SHONA CAUSATIVE
}

\author{
Scott Myers \\ University of Texas
}

In Shona (Bantu: Zimbabwe), the causative form of a verb is formed in one of two ways: either with the suffix -is-/-es- or by changing the root final consonant to a corresponding coronal continuant. The author argues for an analysis in which both forms are derived from a common underlying suffix $/ \mathrm{s} /$. The suffixal form is the result of an independently motivated process of epenthesis. The mutation, on the other hand, comes about by fusion of the /s/ with the preceding consonant. This fusion leads in some cases to feature combinations disallowed in Shona. The effects of mutation in these cases can be captured exploiting an active version of Kiparsky's Structure Preservation in terms of "persistent rules".

\section{Introduction}

In Shona, a Bantu language of Zimbabwe, the causative of a verb is formed in one of two ways. The more productive way is to add the verbal suffix -is- -es-, as illustrated in (1) and (2), respectively. 1
(1) a. -bika
'cook'
-bikisa
'make (so.) cook'
b. -bátá
'hold'
-bátísá
'cause (so.) to hold'

1 The final $-a$ in these and all other verbs cited is the unmarked inflectional suffix. It is replaced by $-e$ in some marked inflections such as negative or subjunctive [Fortune 1982].

All forms are from the Zezuru dialect, spoken around Harare. Unless otherwise noted, examples and glosses are from Hannan [1984] and have been checked with Ms. Drusilla Chambati, a speaker of Zezuru Shona. Forms with a reference to Hannan [1984] were found in that work, but were not familiar to Ms. Chambati.

The abbreviations so. and sth. stand for someone and something, respectively. 
(2) a. -enda 'go'
b. -téngá 'buy' -endesa 'make (so. or sth.) go'

The vowel of this suffix is subject to vowel harmony: it is [e] if the preceding vowel is mid, otherwise it is [i].

The second way of forming a causative involves changing the last consonant of the root, as in (3).

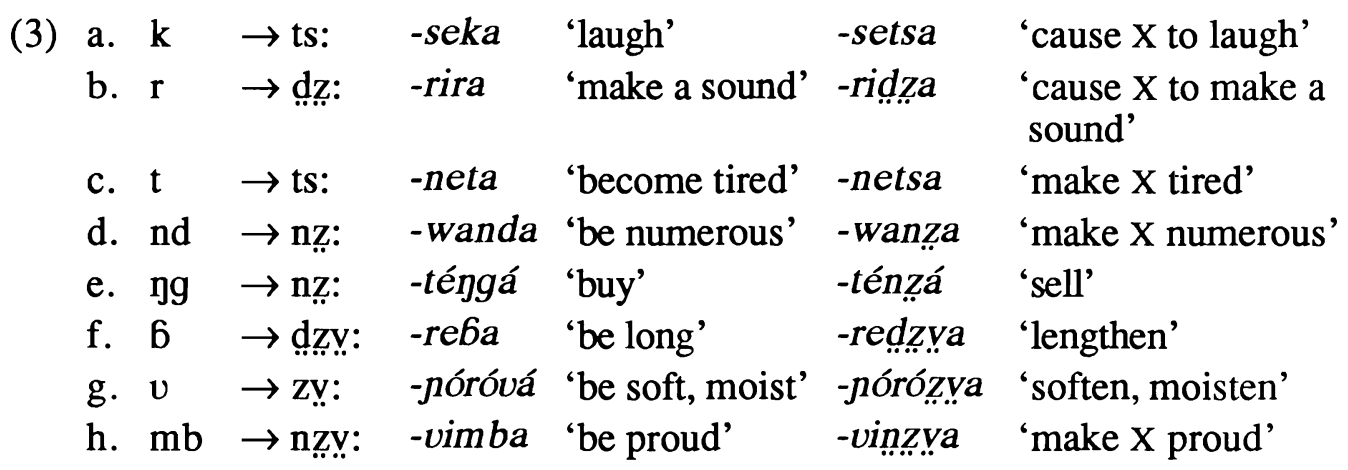

This change I refer to as the causative mutation.

The choice of causative type is an arbitrary lexical property of a given stem; there is no way to predict whether the causative of a stem will be formed with the productive causative or the consonant mutation. Indeed, some radicals take both allomorphs, in which case the mutation often indicates a more direct causation, e.g., -kwídzá 'lift up' vs. -kwirísá 'make someone climb' (cf. -kwírá 'climb'). Another doublet is -ténzá in (3) vs. -téngésá in (2), both derived from -téngá 'buy' and both meaning 'sell'.

One observes that all the mutated consonants in (3) have in common an alveolar fricative articulation, a feature that distinguishes them from the corresponding unmutated form. It is striking that the consonant in the other causative form, as in (1) and (2), is also an alveolar fricative. In this paper, I will argue for an analysis that derives the two forms of the causative from a common underlying form. ${ }^{2}$

\footnotetext{
2 The basic idea here is due to Carter and Kahari [1979: 24]: "The vowel [in the causative suffix] is frequently omitted after - $t$-: -net-s- 'make tired, annoy' from -net- 'become tired'. In some cases the last consonant of the radical fuses with the causative ...". This is all they have to say about the matter, aside from giving a few examples of the mutation. But it is the same basic proposal as I am pursuing here, and quite different from the analysis given in Fortune [1955, 1982], according to which the causative mutation is triggered by an abstract reflex of Proto-Bantu * $\hat{y}$ [Fortune 1955: $212]$. The problem with this historically-based analysis when interpreted synchronically is that the putative $* \hat{y}$ (Guthrie's $* \hat{j}$ ) never surfaces in Shona and does not have palatalization effects, as it does in other Bantu languages (on which see Section 5 below).
} 
(4) a. There is just one causative suffix /-s/, found both in the productive cases in (1) and (2), and in the mutation cases in (3).

b. This /-s/ can be fused with the preceding consonant to form a complex continuant, e.g., an affricate or prenasalized fricative. This is the mutation.

c. If this optional fusion does not take place, a productive rule of epenthesis results in the insertion of the default vowel [i]. This is the productive suffixation.

After establishing some representational assumptions in Section 1, I present in Section 2 an argument for the epenthesis of [i], posited in (4c). I then formulate the "fusion" posited in (4b), by which a sequence of a consonant and [s] are turned into a single complex continuant. I will argue that this one rule of fusion can derive all the causative mutation effects, provided that the notion of "structure preservation" [Kiparsky 1985] be interpreted in terms of "persistent rules" [Halle and Vergnaud 1987, Myers 1991]. In Section 5, I conclude with a look at the causative in other Bantu languages and the historical development of the Shona case.

\section{The Consonants of Shona and their Representation}

The (surface) consonant inventory of Shona is given in (5), asterisks indicating gaps.

$$
\text { Labial Coronal Labio- Alveo- Palatal Velar Laryngeal }
$$
coronal palatal

a. Stops

voiceless

voiced

murmur

prenasal

b. Fricatives

voiceless

voiced

murmur

prenasal

c. Affricates

voiceless

voiced

murmur

prenasal $\mathrm{t}$
$\mathrm{d}$
$\mathrm{d}$
$\mathrm{nd}$

$\mathrm{mb}$

$\begin{array}{cc}\mathrm{p} & \mathrm{t} \\ \mathrm{b} & \mathrm{d} \\ \mathrm{b} & \stackrel{\mathrm{d}}{\mathrm{m}} \\ \mathrm{mb} & \mathrm{nd}\end{array}$

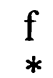

v.

my

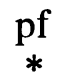

$\underset{*}{b y}$

\section{$\mathrm{s}$}

$\mathrm{z}$

nz

ts

*

$\stackrel{\mathrm{dz}}{*}$

sv
$*$
Zy
nzy

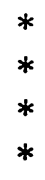

$*$
$*$
$*$
$*$

$$
\begin{aligned}
& \check{\mathbf{s}} \\
& * \\
& \check{Z} \\
& *
\end{aligned}
$$

tsv
$*$
dzgy
$*$

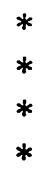

$*$
$*$
$*$
$*$

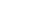

$\begin{array}{cc}\mathrm{k} & * \\ * & * \\ \mathrm{~g} & * \\ \mathrm{gg} & *\end{array}$

$$
\begin{aligned}
& * \\
& * \\
& *
\end{aligned}
$$




\section{Labial Coronal Labio- Alveo- Palatal Velar Laryngeal}

d. Sonorants

$\begin{array}{llllllll}\text { nasal/vd } & \mathrm{m} & \mathrm{n} & * & * & \mathrm{n} & \mathrm{y} & * \\ \text { nasal/mur } & \mathrm{m} & \mathrm{n} & * & * & * & * & * \\ \text { liquid } & \mathfrak{v} & \mathrm{r} & * & * & * & * & * \\ \text { murmur } & * & * & * & * & * & * & \text { n }\end{array}$

In the representations of the consonants in (5), I assume the following set of hierarchically organized features, from McCarthy [1988].

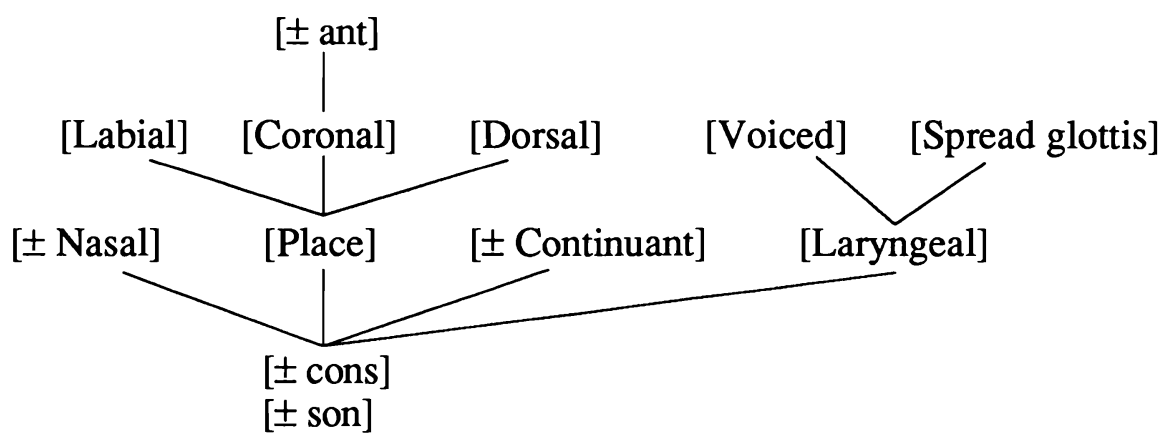

However, nothing in the analysis hinges crucially on the particular hierarchy chosen, and the main points would be unaffected if we assumed another model, e.g., that of Sagey [1986].

Among the places of articulation given in (5), the only one that might be unfamiliar is "labiocoronal". These are fricatives or affricates, produced with two simultaneous fricative occlusions: a bilabial one and an apico-alveopalatal one [Doke 1931: 87]. They are called "whistling" fricatives, and we represent them, as in the conventional orthography, with the digraphs $s v$ and $z v$. It should be emphasized, however, that these are not sequences: the two articulations are simultaneous. They will be represented as complex segments with both labial and coronal specifications, as in (7).

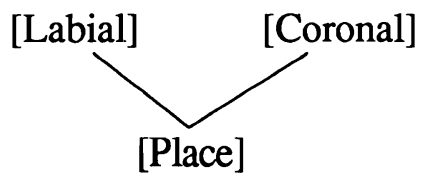


These segments are phonetically also [-anterior] (i.e., alveopalatal), but this specification plays no role in the phonology, and I will assume that it is introduced by a late default rule.

There is a three-way laryngeal distinction: voiceless, plain voiced, and murmur-voiced. The first two are as in English. The murmured consonants are characterized by breathy voicing and extremely low pitch (lower than low tone on a vowel); they are also known as "depressor" consonants. ${ }^{3}$ We indicate murmur by a pair of subscript dots, as in $\underset{n}{b}$ or $m .4$ The murmured / $/ \mathbf{f} /$ is like English $/ \mathrm{h} /$ in that it has no intrinsic tongue position and simply takes over the articulation of the following vowel. It differs in that it is voiced and murmured.

Murmur will be represented by the combination of the privative laryngeal features [spread glottis] (i.e., breathiness) and [voiced] (cf. Lombardi [1991]). Voiceless obstruents, on the other hand, are unmarked. The laryngeal specifications for obstruents will thus be as in (8).

a. Voiceless

b. Plain Voiced

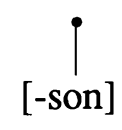

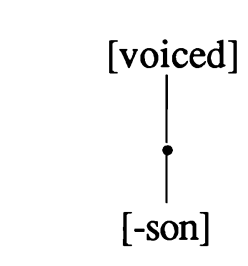

\section{(1)}

c. Murmur Voiced

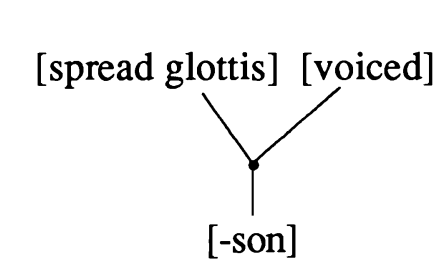

Laryngeal node:

Root node:

The plain-voiced implosive stops [6] and [d] appear frequently in native morphemes and alternate with plain-voiced explosive [b] and [d]. The plain voiced allophone appears when prenasalized or before a following [w], the implosive appears elsewhere, i.e., in the cases in which the stop is alone in the onset. These plain-voiced stops contrast with murmur-voiced [b] and [d]], which appear mainly in loan morphemes and do not participate in any alternations. 5 I therefore represent the implosives as underlyingly plain-voiced, as in (8b), with implosion a redundant addition. They therefore differ underlyingly from the murmurvoiced stops only in that the latter bear the additional feature [spread glottis].

There is only one voiced velar plosive: the murmur-voiced [g̈]. But although this segment would be classed phonetically with the murmur-voiced [b] and [d]], it patterns phonologically with the plain-voiced stops. It appears frequently in native morphemes and alternates with the plain-voiced [g] (e.g., when pre-

\footnotetext{
3 Pongweni [1981,1984] provides instrumental data on this distinction in Shona, and Traill et al. [1987] is an excellent instrumental study of the corresponding consonants in Zulu.

4 The dots will be superscript in [g̈] to keep them visible. In the standard orthography, murmur is indicated by a digraph with $h$, e.g. bh or $m h$.

5 For example, the voiced stops of English typically appear in Shona as murmured stops: (e.g., bázi ‘bus' or dóra 'dollar'.
} 
nasalized). Therefore, I analyze it as underlyingly plain-voiced, its murmur specification added late in the derivation like the implosion specification of [6] and $[d]$.

All voiced continuants are murmured. I will assume that they are underlyingly specified just as voiced, as in (8b), and that the redundant [spread glottis] specification is introduced by a late default rule.

To summarize, in the discussion that follows I will systematically ignore various redundant laryngeal specifications apparent in the surface forms: [constricted glottis] in implosives, and [spread glottis] in fricatives, affricates and velar stops. The relevant phonological classifications will thus be as in (9).

(9) a. No Laryngeal Specification (as in (8a)): voiceless obstruents.

b. Plain-Voiced (as in ( $8 \mathrm{~b})$ ): $/ \mathrm{b}, \mathrm{d}, \mathrm{g} /$, voiced fricatives and affricates, plainvoiced sonorants.

c. Murmur-Voiced (as in (8c): /ḅ, d, m, ṇ.

This rather abstract categorization corresponds to that underlying the orthography. Only the consonants in (9c) are written with the $h$ indicating breathyvoicing (i.e., $b h, d h, m h, n h$ ); those in (9b) are written without $h$ even when they are phonetically breathy-voiced (e.g., orthographic $z$ and $g$ ).

More generally, I will assume a hypothesis of contrastive underspecification, according to which only redundant feature specifications are absent from underlying forms [Steriade 1987, Mester and Itô 1989]. Continuancy, for example, is contrastive for obstruents, but predictable for sonorants. We thus include a specification for [continuant] in the representation of any obstruent, but not in that of a sonorant. All place specifications will likewise be specified, except for the redundant [+anterior] specification of labiocoronals. Crucially, the analysis below cannot be made to work if one assumes a hypothesis of radical underspecification [Kiparsky 1981, Archangeli and Pulleyblank 1986], according to which only one value may be specified underlyingly for any given feature.

Following Sagey [1986], affricates and prenasalized segments are represented as contour segments, i.e., sequences of conflicting features connected to a single root node. An affricate is thus represented as in (10a), and a prenasalized segment as in (10b). 6

6 I will assume that, as in (9b), a prenasalized obstruent is [-son], i.e., that its major class features reflect those of its oral portion. This assumption proves useful below in the account of the prenasalization of $/ \mathrm{r} /$. 

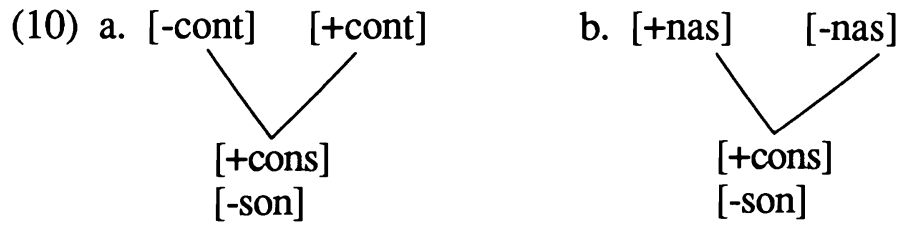

It is contour segments of these two sorts that are produced by causative mutation, and which are the key to the understanding of this process.

Finally, a note on notation. A line in a rule will indicate not association, but connection; two nodes A and B are connected iff they are dominated by the same root node. I assume this convention in order to avoid cluttering rules with predictable and irrelevant intervening nodes.

\section{Epenthesis}

As suggested above in (4), the productive causative -is- can be derived on the basis of an underlying suffix of the form $/ \mathrm{s} /$. All we need is a rule epenthesizing [i], and it turns out that such a process is independently motivated in Shona. ${ }^{7}$

The causative suffix has the form -is- or -es-, as shown in (1) and (2), respectively, when it has been suffixed to a verb radical. The causative is usually suffixed to a verb radical, and verb radicals are always consonant-final. But the causative can also be added to adjective stems, which always end in a vowel. In these cases, the $-s$ - appears without a preceding i/e vowel, as in (11) (from Fortune [1982: 27]).
a. -pfúp
'short'
-pfúpí-s-á
'shorten'
b. -dúku 'small'
- đúkú-s-á
'make small'

The same pattern of $\mathrm{V} \sim \varnothing$ alternation is evident with the other verbal suffixes, as in (12) and (13).

(12) The neuter passive suffix: $-i k-\sim-e k-\sim-k-$
a. -6ik-a 'cook'
-vereng-a 'read'
$-6 i k-i k-a$
'be cookable'
b. páru
'idph. of tearing'
-vereng-ek-a
koche
'idph. of joining
-párú-k-á
'be readable'
by hooking together'
-pfúpi 'short'
-tsvene 'pure'
-koche-k-a
'get torn'
-kobvu 'thick'
-pfúpí-k-á
-tsvene-k-a
-kobvu-k-a
'get joined by being
hooked together'
'be short'
'be pure'
'be thick'

7 Watkins (1937) made a similar proposal for the Bantu language Chichewa, describing the vowels of the verbal suffixes as "connecting vowels" which are "determined on a purely phonetic basis" (p. 47). 
(13) The applicative suffix: $-i r-\sim-e r-\sim-r-$
a. -6ik-a 'cook'
-vereng-a 'read'
-6ik-ir-a
-veremg-er-a
'cook for'
'read for'
b. páru
'idph. of tearing'
gaší
'idph. of receiving (esp. in hands)'
ma-kókó 'pot scrapings'
cha-púpu
'witness'
-párú-r-á
-gaši-r-a
-kókó-r-á
-púpú-r-á
'tear'
'receive (esp. in hands)'
'scrape (a pot)'
'give evidence'

These suffixes, like the causative, appear in their vowel-initial form when they are suffixed to verb radicals, i.e., when they follow a consonant. But they appear without the vowel when they are suffixed to vowel-final adjectives, nouns or ideophones, as in (12b) and (13b). 8

The passive morpheme shows the same alternation, but under somewhat different conditions.

(14) The passive suffix: $-i w-\sim-e w-\sim-w-$
a. -úráy-á 'kill'
-úráy-íw-á
'be killed'
-téy-á 'trap'
-téy-éw-á 'be trapped'
-pfúw-á 'raise cattle'
-pfúw-íw-á
'be raised (cattle)'
$\begin{aligned} \text { b. }-d-a ́ & \text { 'love' } \\ -p-a ́ & \text { 'give' }\end{aligned}$
$-d-i ́ w-a ́$
'be loved'
-p-íw-á
'be given'
c. -bát-á 'catch, hold'
-vereng-a 'read'
-bik-a 'cook'
-rip-a 'pay for'
-6át-w-á
-verejg-w-a
$-6 i k-w-a$
-rip-w-a
'be caught, held'
'be read'
'be cooked'
'be paid for'

8 The examples in (11b) and (12b) are drawn from Fortune [1955, 1982]. Suffixation of extensions to ideophones (idph.) or substantives to make verbs is by no means straightforwardly productive. For a survey of the glitches and subgeneralizations, see Fortune [1982: 19-27].

A reviewer points out that with ideophone bases ending in $o$ or $u$, it becomes difficult to distinguish the applicative and neuter passive suffixes from the reversive suffixes -ur-/-or-and -uk-/-ok-, as in -namura 'unseal' and -namuka 'get unsealed' (cf. -nama 'plaster, cover'). I have taken the hallmark of the reversive-ur- to be the interpretation "reverse the action of V-ing". The applicative $-r-$, on the other hand, adds an internal argument [Alsina and Mchombo 1989], which in the case of an ideophone (which takes no arguments), will just make the resulting verb transitive. Likewise the reversive - $u k$-means 'get un-V-ed', while the neuter passive $-k-$ suppresses an external argument, resulting in an intransitive.

The reviewer also suggests that it might be that the ideophone was derived from the verb in these cases, by a process of subtractive morphology. This account would however have to explain why the consonant deleted from the verb to form the ideophone was always one of those associated with one of the verbal suffixes. 
The vowel-initial form appears after a glide, as in (14a), or after a radical consisting just of a consonant, as in (14b). Otherwise it appears without the vowel, as in $(14 c)$.

We have a vowel-zero alternation and so could in principle posit either a vowel deletion or a vowel epenthesis. The quality of the alternating vowel is predictable, being either [e] or [i], depending on vowel harmony. Its position is also predictable, since it occurs only between consonants. The properties of the vowel are therefore redundant, and it should be omitted from underlying representation. This indicates that an epenthesis analysis is to be preferred. ${ }^{9}$

The epenthesis clearly depends on syllable structure. Syllables in Shona, as in many Bantu languages, are of the form $(C)(w) V$, i.e., they are all open and allow only a single consonant in the onset, or a sequence of a consonant and a glide. There are no consonant-final words and no consonant clusters except for Cw. 10 When a consonant cluster or word-final consonant appears in a loanword, a vowel is inserted to maintain the $(C)(w) V$ syllable structure.
a. ápirikoti 'apricot'
b. sikurúdiraiya 'screwdriver'
c. sitiróngo sitáfu 'potent alcoholic drink (i.e., strong stuff)'11
d. dọráikirína 'dry cleaner'
e. dirámu 'drum (metal)'

The inserted vowel is generally [i], although one also finds [u] after velars or labials $(15 c, e)$, or a copy of a preceding or following vowel $(15 b, c)$. I will assume that what is inserted is an empty position, which is filled either by default rules as [i], or by processes of assimilatory spread from neighboring consonants or vowels.

The epenthesis in verb suffixes can be seen as another instance of the same pattern: the default vowel [i] is inserted to break up unsyllabifiable consonant clusters. In order to capture the relation between epenthesis and syllabifiability, I

9 There is a process in Shona deleting vowels in hiatus in some morphological contexts, but it is always the first vowel that is lost: $\underline{n d-a-b i ́ k a ~ ' I ~ c o o k e d ' ~ v s . ~ n d i-n o ́-b i k a ~ ' I ~ c o o k ', ~} d z$-ósé 'all (cl 10)' vs. $i-d z i$ 'these (cl. 10)' [Myers 1987: 220-261]. This deletion process thus cannot be responsible for the alternations in the verbal suffixes.

10 These sequences, orthographically represented by a consonant symbol followed by $\mathbf{w}$, have often been interpreted as complex segments with a secondary labio-velar articulation [Doke 1931, Sagey 1986]. Recent instrumental studies by Ian Maddieson, however, indicate a clear succession of elements, with release of the consonant before the onset of the labio-velar articulation [Maddieson 1989]. I therefore follow Maddieson (and Myers 1987) in interpreting these sounds as clusters.

Depending on dialect, the velar portion of the cluster varies in degree of stricture from a stop to a semivowel. The sequence written pw, for example, can be pronounced [pk] or [px] or [pw] [Doke 1931].

11 This example is taken from a recent issue of the Shona newspaper Kwayedza. 
adopt the approach of Halle and Vergnaud [1979], Selkirk [1981] and Itô [1989], according to which epenthesis is built into the syllabification process. When a sequence of segments is unsyllabifiable because it includes no segment that can stand as a nucleus, we can construct a "degenerate" syllable with an unfilled nucleus position. This position is then filled by the default vowel. This is illustrated in (16), a derivation of the causative stem -bikisa from (1a).

(16) a.

-6 i k-s-a b.

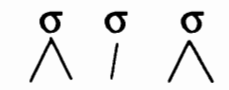

-6 i $k-s-a$ c.

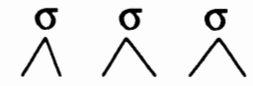

-6 i k - i s - a

The underlying form in (16a) is syllabified as in (16b), with a degenerate syllable without nucleus erected over the otherwise unsyllabifiable $[\mathrm{k}]$. The default vowel [i] is then inserted to fill the empty slot, yielding (16c).

The conditions on epenthesis are somewhat different for [w] because it has a special status in syllable structure: it is the only segment that can fit between a consonant and a vowel in the same syllable. The passive marker $-W$ - can generally appear after a consonant-final radical without an epenthetic vowel because it can form a complex onset with almost any preceding consonant. The one exception is where the preceding consonant is a glide: there are no sequences of glides in Shona, so we must exclude such sequences as possible onsets, presumably by reference to sonority. A sequence of a glide followed by the passive $-w$ - will therefore be unsyllabifiable without epenthesis. ${ }^{12}$

I conclude that the basic form of these verbal suffixes is monoconsonantal: causative /-s-/, applicative /-r-/, neuter /-k-/, and passive /-w-/.

\section{Causative Mutation}

We can now turn to the analysis of the causative mutation, summarized in (17). The radical-final consonants to the left of each arrow correspond to the mutated consonants to the right.

12 The vowel [i] is also inserted before monosyllabic stems, as in ig̈o "wasp" (cf. ne-g̈o "with a wasp', ma-g̈o 'wasps'), or ibỵá 'leave!' (cf. ibya 'to leave', a-byá 'he left').This $i$ appears only before monosyllabic stems, and only if they are not preceded by any clitic or prefix in the same phonological word. In this case, we can say that epenthesis enforces the requirement that a phonological word have at least two syllables (i.e. one binary foot) [Myers 1987: 128-134].

I have no explanation as to why there must be epenthesis with monoconsonantal roots, as in -píwá, the passive of -pá 'give' in (14b). Certainly [pw] is a possible onset, as in the verb stem -pwanya 'crush', and it is possible to have a monosyllabic stem as in the active -pá. A reviewer suggests that the root could be analyzed as /pi/, with the vowel deleting before a vowel (cf. fn. 9) and surfacing elsewhere. The problem would be then to explain why all CV roots have [i] as the V, since all roots of this form take $\mathrm{i} / \mathrm{e}$ in the passive. 


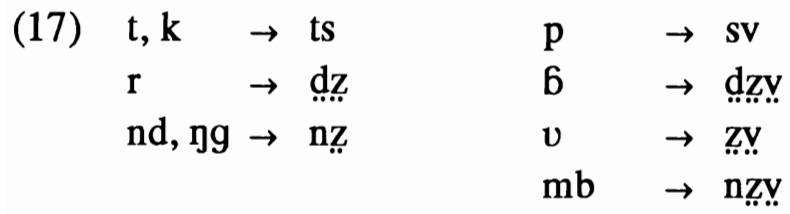

These are the only consonants for which there are attested examples of mutation. Asked for causatives of roots ending in other consonants, my consultant would only accept forms in -is- or -es-. Moreover, of the mutations in (17), the only fully productive ones are $\mathrm{r} \rightarrow \mathrm{dz}$ and $\mathrm{k} \rightarrow \mathrm{ts}$, which occur in hundreds of examples. In all other cases, the examples I give are all that I have been able to find.

Any of the consonants in (17) can be followed by the more productive causative with epenthetic vowel, as we see in (18).
a. -6ika 'cook'
-bikisa
'make (so.) cook'
b. -Gárá 'bear offspring'
-6árísá
'impregnate'
c. -6áta 'hold'
-bátísá
'cause (so.) to hold'
d. -enda 'go'
-endesa
'make (so. or sth.) go'
e. -téngá 'buy'
-téngésá 'sell'
f. -rapa 'cure'
-rapisa 'help (so.) to cure or be cured'
g. -fámbá 'move (intr.)'
-fámbísá 'deliver'

There is, then, no radical-final consonant that is incompatible with the epenthesis. Indeed, as we noted above, some radicals take both allomorphs, e.g., -kwidgáa 'lift up' vs. -kwírísá 'make someone climb' (cf. -kwírá 'climb'), or -ténzá 'sell' vs. -téngésá 'sell' (cf. -téngá 'buy'). There is no way to predict which causative form a given radical will occur with.

As I pointed out above, the one thing all the mutated forms have in common which distinguishes them from the corresponding unmutated forms is an alveolar fricative articulation, i.e., an [s] or [z] component. I have attributed this component to a causative suffix of the form $/ \mathrm{s} /$. There are two questions that must be answered, however, to make this analysis work. One, how does the sequence of a consonant and /s/ come to be a single complex consonant? Two, what is responsible for the other changes in the mutated as compared with the unmutated form: changes in place of articulation, degree of stricture and voicing?

In answer to the first question, I propose the following coalescence operation. 
Affrication
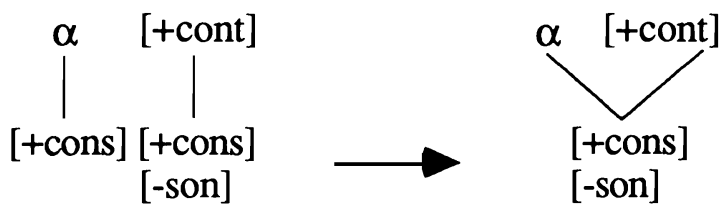

Affrication fuses a continuant with a preceding consonant by unifying the two root nodes of the successive consonants. If the preceding consonant is a stop, this will produce an affricate. Some such rule must be quite common crosslinguistically, to account for the rarity of a contrast between affricates and stopfricative clusters.

The rule is optional; if it fails to apply, the unsyllabifiable [s] will trigger epenthesis, producing what we have called the productive causative. The rule only induces alternations within verb stems, so it must be a lexical rule. I follow Kiparsky [1982] in assuming that the output of each lexical cycle is stored in the lexicon, which allows the speaker to keep track of whether the rule applies with a particular root. ${ }^{13}$ The lexical blocking effect [Aronoff 1976, Kiparsky 1982] will then account for the fact that a given root generally only has one causative form, and for the semantic differentiation of the few cases of causative doublets like -kwídzá /-kwírísá. 14

Consider the simplest causative mutation, in which the sequence $t+s$ is reorganized into the affricate [ts]. Instances of this alternation are given in (20).

$$
\begin{aligned}
& \mathrm{t} \sim \mathrm{ts} \\
& \text {-neta 'become tired' } \\
& \text {-rótá 'dream' }
\end{aligned}
$$

[Fortune 1955: 212]

The cluster $\mathrm{t}+\mathrm{s}$ cannot simply surface as a cluster, since Shona syllable structure does not allow such a cluster. 15 The derivation of the affricate would run as in (21).

\footnotetext{
13 An optional postlexical rule would of course have quite a different effect. Because the output of postlexical operations are not stored, an optional postlexical rule produces a pattern of free variation.

14 Bastin [1986: 116] notes a similar pattern of semantic differentiation in causative doublets in a number of Bantu languages.

15 The [ts] in these forms cannot be a heterosyllabic cluster because [t] cannot appear in a coda position, i.e., it never appears word-finally nor before any consonant but [s]. Nor can it be interpreted as an onset cluster, since then one would expect to find sequences of [t] followed by fricatives other than [s], or by more sonorous elements such as [r], [y], and [w]. We conclude that the orthographic $t s$ in Shona is a monosegmental affricate. Similar arguments rule out a cluster analysis for the other affricates and the prenasalized segments.
} 
Epenthesis, mutation, and structure preservation in the Shona causative
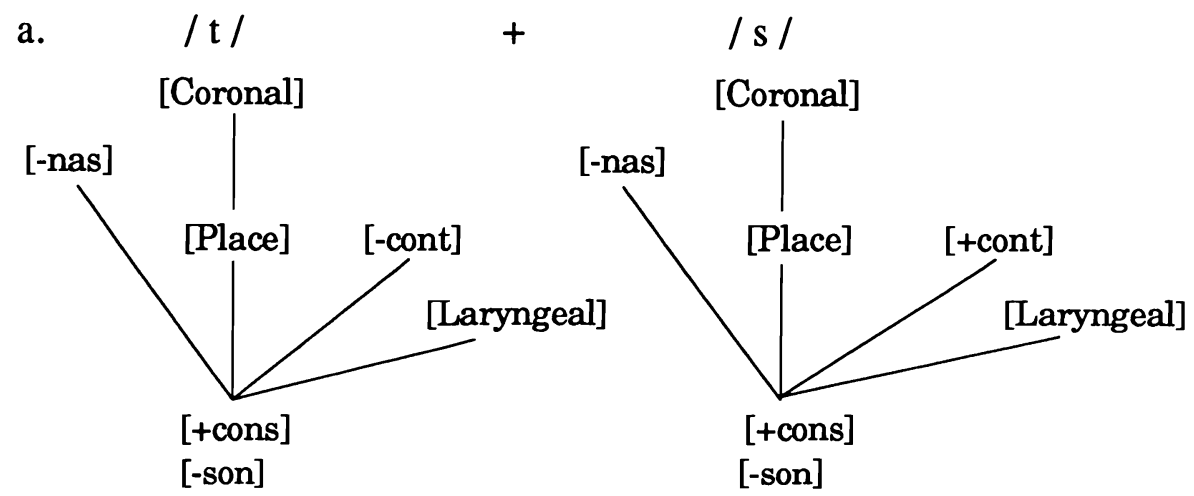

b. Affrication

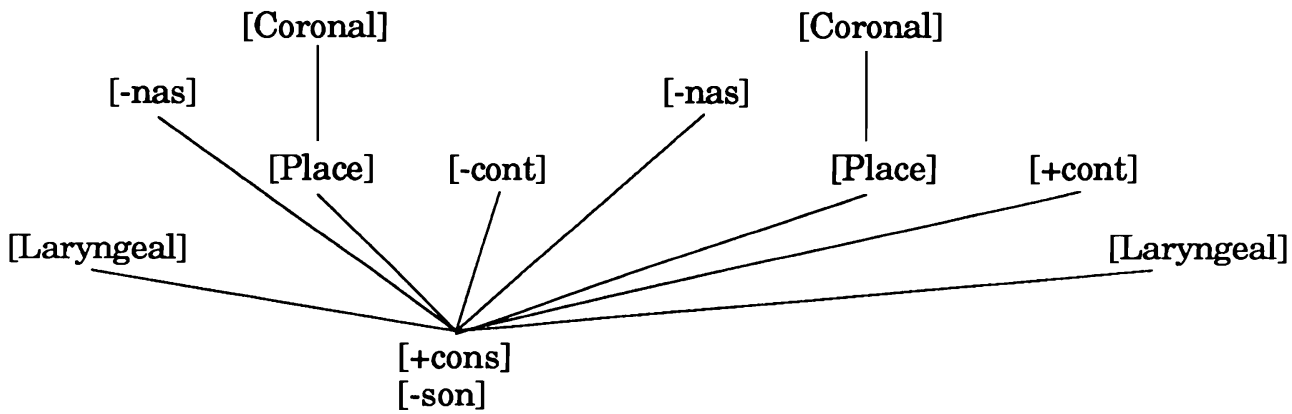

c. Twin Sisters Convention

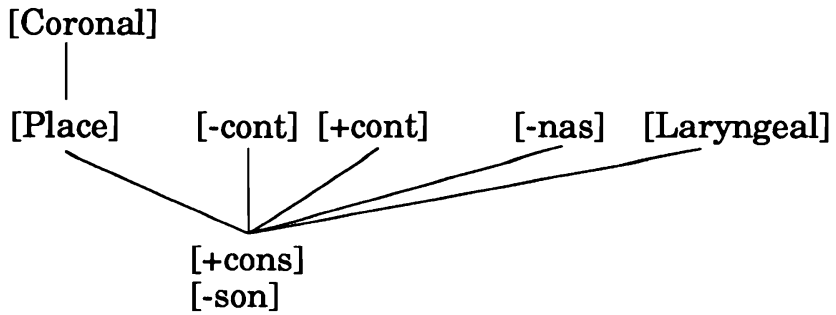

We begin, in (21a), with the sequence of the stem-final [t] of /net/ followed by the causative $/ \mathrm{s} /$. In the first step (21b), the root node of the continuant is unified with that of the preceding stop, creating an affricate, i.e., a sequence of [-cont] followed by [+cont] associated with the same root. 
The representation is then pruned in (21c) by the Twin Sisters Convention [Clements and Keyser 1983: 95]: two identical specifications associated with the same element are converted to a single such specification. 16 According to this convention, for example, two high tones associated with the same tone-bearer never contrast with and never behave differently from a single high tone associated with a tone-bearer (e.g., Odden [1981: 211]). In (21b), we have two Place nodes associated with the same root node, so these are fused together into one. Then we have two Coronal nodes associated with the same Place node, so those are fused into one. The final result is (21c): a single affricate with a stop portion from the $[t]$ and a fricative portion from the [s].

The most productive of all the causative mutations takes the sequence $r+s$ and converts it into [d] ]. Examples are given in (22).

\begin{tabular}{|c|c|c|c|}
\hline -rira & 'make a sound' & -ridza & 'cause (sth.) to make a sound' \\
\hline -rárá & 'lie down' & -ráḍẓá & 'bury' \\
\hline -fára & 'be happy' & -fáḍza & 'make (so.) happy' \\
\hline -pér & 'come to an end' & -péḍzáá & 'bring (sth.) to an end' \\
\hline$-y$ & 'come to a boil' & - yaiḍza & 'bring to a boil' \\
\hline -zá & 'be full' & -zádzá & 'fill' \\
\hline
\end{tabular}

The resulting affricate has the voicing of the first consonant, and the continuancy of the second, just as we would expect from our formulation of Affrication. But how does the sonorant [r] become an obstruent stop articulation within the affricate?

It should first be noted that the [r] in Shona in fact has a lot in common with [d]: they're both voiced, coronal consonants with closure at the alveolar ridge. All that distinguishes them is that the duration of that closure, which in the [r] is a mere tap or sequence of taps [Doke 1931: 72]. Moreover, [r] does alternate with [d] in another environment, namely after a nasal in a prenasalized segment:

$$
\begin{array}{lll}
\text { mu-refú } & \text { 'long (1)' } & \text { ndefú 'long (9/10)' } \\
\text {-ramba kuúdzwá 'refuse to be } & \text { ndambakuúdzwá 'unruly person' (9/10) } \\
\text { told' } &
\end{array}
$$

In these examples, the class $9 / 10$ marker / $\mathrm{n} /$ has been juxtaposed with a stem beginning with [r], and the two consonants end up fused into a single prenasalized

16 This requires a slight generalization of Clements and Keyser's convention to include nodes as well as feature specifications, and the assumption that, for example, a Place node is identical with any other Place node. The convention, so interpreted, subsumes the Shared Feature Convention of Steriade [1982: 48] and the "no branching class nodes" convention of Sagey [1990: 50]. 
consonant [nd]. I therefore propose that $[\mathrm{r}]$ and [d] be distinguished only by the feature [sonorant], as in (24).

(24)

a. $[\mathrm{r}]$

[Coronal]

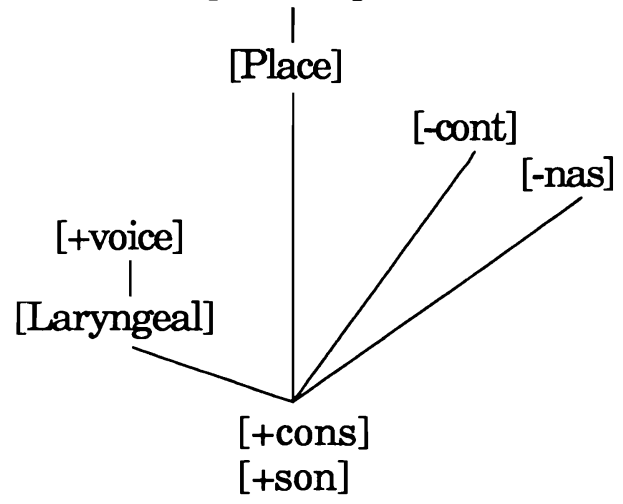

b. [d]

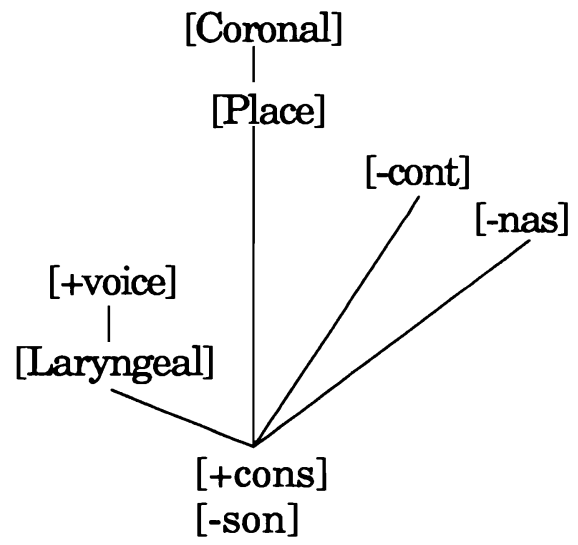

Now consider the application of Affrication to the sequence $r+s$. The root node of $/ \mathrm{r} /$, which is [+son], will be unified with that of $/ \mathrm{s} /$, which is [-son], raising a question of priority. All consonants resulting from the causative mutation are obstruents, so apparently it is always the [-son] of /s/ that "wins". I have encoded this into the Affrication rule by specifying the output as [-son]. In the case of $r+s$, the result will be that Affrication will have as a side effect the change of $/ r /$ to $[d]$, as in (25).

a. $\quad / r /$

[Coronal]

[Place]

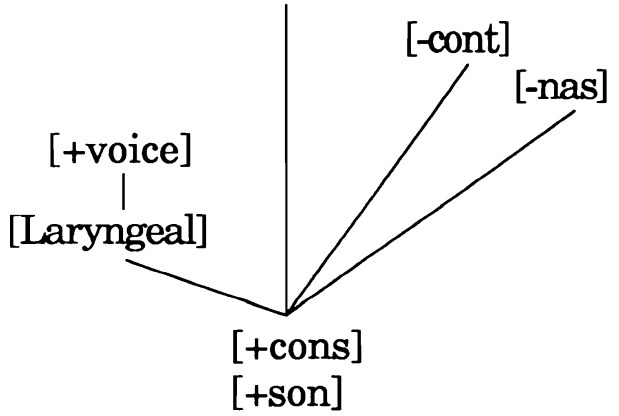

/ s /

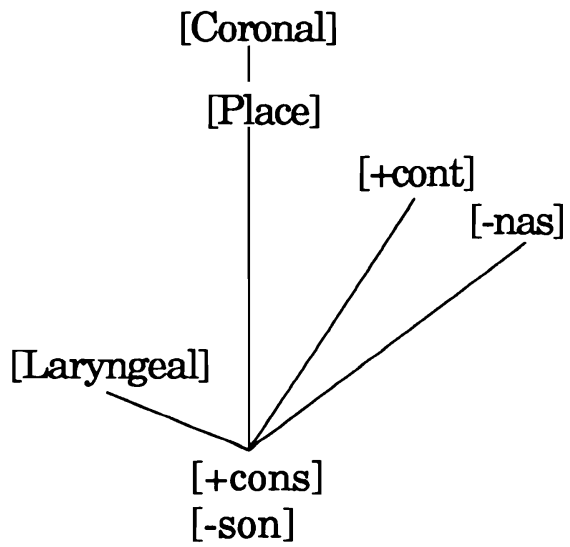


b. Affrication

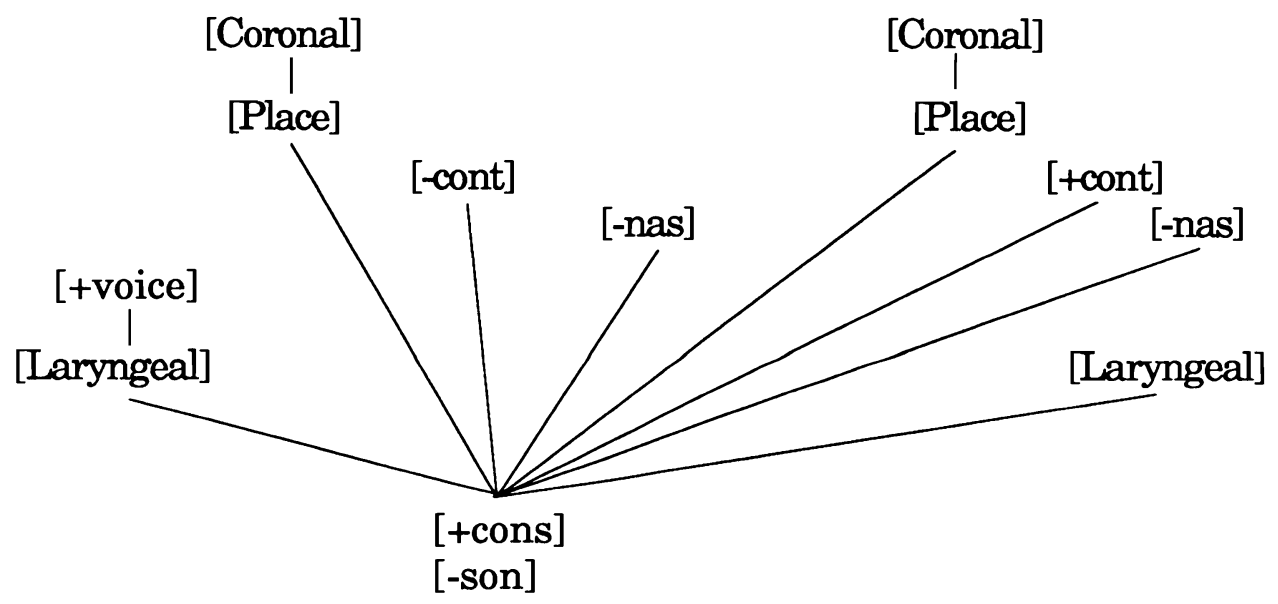

c. Twin Sisters Convention

[Coronal]

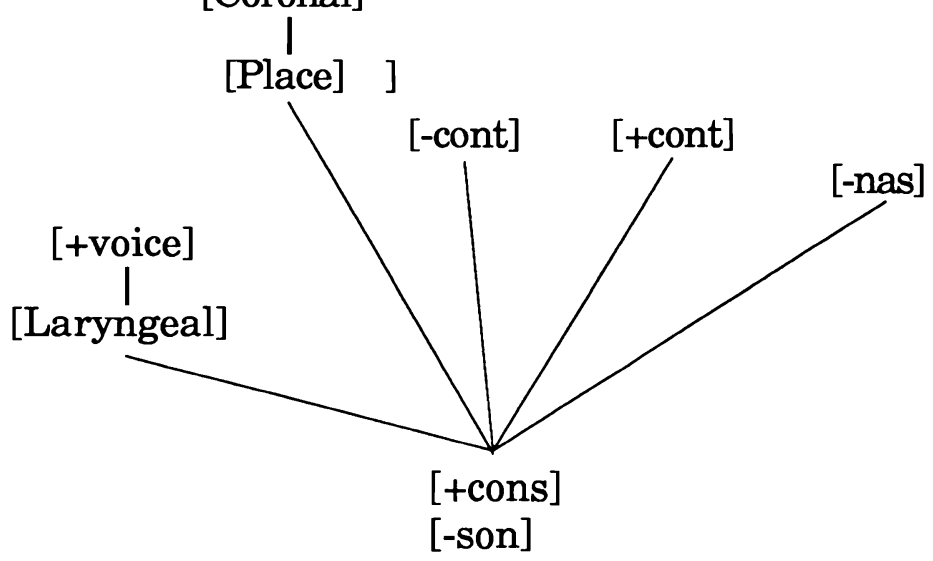

The input sequence is given in (25a). Affrication results in the single segment shown in (25b), which is pruned in accordance with the Twin Sisters Convention to yield (25c). This representation is voiced because the /r/ was voiced and the /s/ had no laryngeal specification. It is coronal and non-nasal because those are properties of both input segments. It has a stop portion from the / $\mathrm{r} / \mathrm{and}$ a fricative portion from the /s/. It is [-son] as a side-effect of Affrication. In short, it is the voiced alveolar affricate [dz]. 


\section{Affrication and Structure Preservation}

The other instances of the mutation are less trivial in that the mutated consonant is not merely the sum of the features of the unmutated consonant with those of $/ \mathrm{s} /$. The mutation of $/ \mathrm{k} /$ to the coronal affricate [ts], for example, involves a change in place of articulation as well as affrication.

In all such cases, as we will see, application of Affrication as formulated would produce a segment type that is not attested in Shona. Application of the rule to the sequence $\mathrm{k}+\mathrm{s}$, for example, would create a coronal-velar affricate, which is neither a phoneme of Shona nor a surface phone.

Causative mutation in Shona is structure-preserving, i.e., it produces no segment that is not a Shona phoneme. That this is the case is evident from a comparison of the mutated consonants (from (17), repeated here for ease of reference) with the set of [+continuant] phonemes, given in (26).

$$
\begin{array}{llll}
\mathrm{t}, \mathrm{k} & \rightarrow \mathrm{ts} & \mathrm{p} & \rightarrow \mathrm{sv} \\
\mathrm{r} & \rightarrow \mathrm{dz} & 6 & \rightarrow \mathrm{dzy} \\
\mathrm{nd}, \mathrm{gg} & \rightarrow \mathrm{nz} & \mathrm{v} & \rightarrow \mathrm{zy} \\
& & \mathrm{mb} & \rightarrow \mathrm{nzy}
\end{array}
$$

\begin{tabular}{|c|c|c|c|c|c|c|}
\hline voiceless & f & $\mathbf{S}$ & SV & $\check{\mathbf{s}}$ & * & * \\
\hline voiced & $*$ & * & $*$ & * & * & * \\
\hline murmur & y & Z & ZY & Ž & $*$ & * \\
\hline
\end{tabular}

$$
\text { Labial Coronal Labio- Alveo- }
$$

Palatal Velar Laryngeal

a. Fricatives

b. Affricates

$\begin{array}{lccccccc}\text { voiceless } & \text { pf } & \text { ts } & \text { tsv } & \check{c} & * & * & * \\ \text { voiced } & * & * & * & * & * & * & * \\ \text { murmur } & \text { by } & \text { dz } & \text { dzy } & \check{\mathrm{j}} & * & * & * \\ \text { prenasal } & * & * & * & \mathrm{nj} & * & * & *\end{array}$

It is clear that every one of the mutated consonants is also a member of the phoneme set given in (26), i.e., all of them appear in underlying forms independently of the mutation. Thus the mutation is structure-preserving in the sense of Kiparsky [1985]. I would suggest that this is a crucial property, and one that will allow us to account for the remaining mutations in (17).

Let us consider the restrictions on possible [+cont] segments in Shona. One striking property of the set (26) is the fact that it includes no dorsal consonants, neither velars or palatals. There are, then, no dorsal continuants in Shona, 


\section{d. Dorsal Rule (27b)}

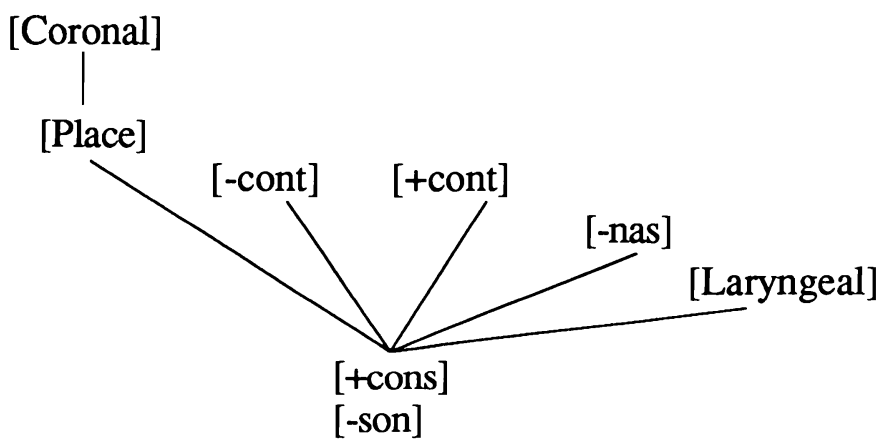

In (29a), we see the sequence $k+s$. Affrication produces (29b), in which two Place nodes are associated to the same Root node. The Twin Sisters Convention therefore applies, producing the representation (29c), which includes a connection between [Dorsal] and [+continuant]. This triggers the persistent rule (27b), which deletes [Dorsal], yielding (29d). This is a coronal segment with a sequence of [-cont] + [+cont $]$, i.e., the desired coronal affricate [ts].

If, on the other hand, we used the filter (27a) to represent the lack of dorsal continuants in Shona, the filter would simply block Affrication, since application of that rule would create a representation violating the filter. The filter, then, incorrectly predicts that an affricate should not result from the sequence $k+s$. The persistent rule makes the right prediction in this case, because it allows the affricate to be formed, but then changes it to something that does not include a dorsal articulation. 19

Another case of the same sort involves another gap in (26). That chart shows that while there is a contrast between fricatives and affricates in Shona (e.g., /s/ vs. /ts/, /f/ vs. /pf/), there is no such contrast in the prenasalized segments. The only prenasalized affricate is the alveopalatal $/ \mathrm{jy} /$, but there is no corresponding prenasalized fricative $* / \mathrm{n} \check{z} /$. On the other hand, there are prenasalized fricatives at the other places of articulation $/ \mathrm{my}, \mathrm{nz}, \mathrm{nzv} /$, but no corresponding prenasalized affricates: $* / \mathrm{mby}, \mathrm{ndz}$, ndzy/. I will take the broad generalization to be that there are no prenasalized affricates in Shona, and will assume that there is a more particular rule governing alveopalatals which takes precedence over the broad generalization by the Elsewhere Condition of Kiparsky [1973]. However, because I have found no alternations involving the alveopalatals, I will not attempt to formulate this particular rule.

19 In the Athapaskan language Slave a general process turning fricatives into affricates must, as in Shona, be prevented from creating a non-phonemic dorsal affricate. In Slave, however, it is the fricative component of the affricate which is sacrificed, not the dorsal articulation, so the result is the dorsal stop $g$ [Rice 1987]. 
Assuming the persistent rule (27b), we derive these affricates straightforwardly as in (29).

(29) a.
$/ \mathrm{k} /$
$+$
/s /
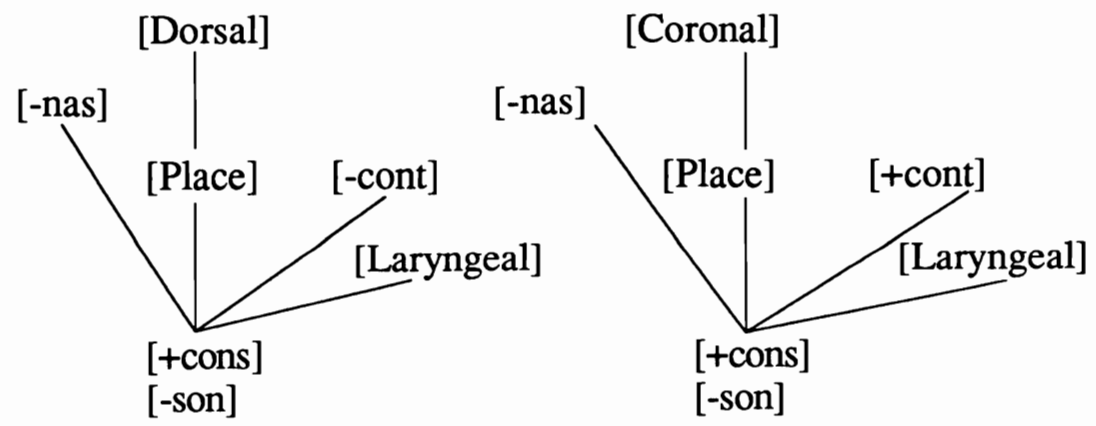

b. Affrication

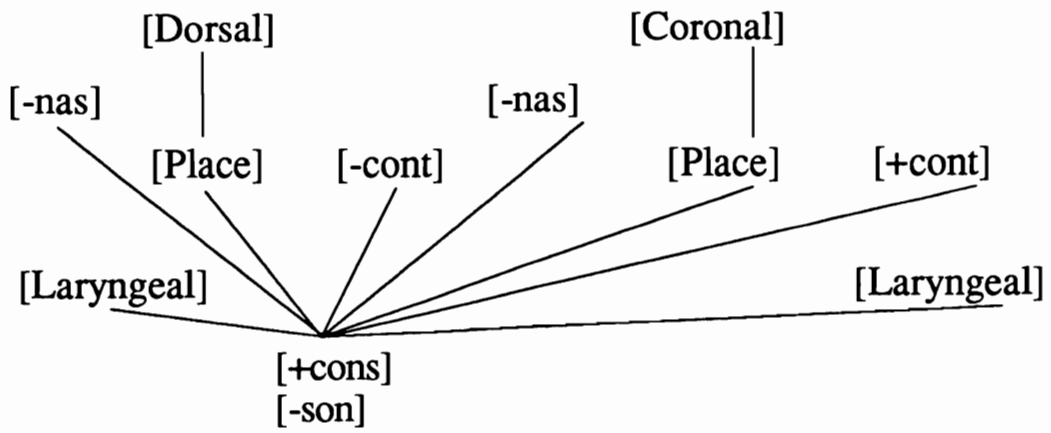

c. Twin Sisters Convention

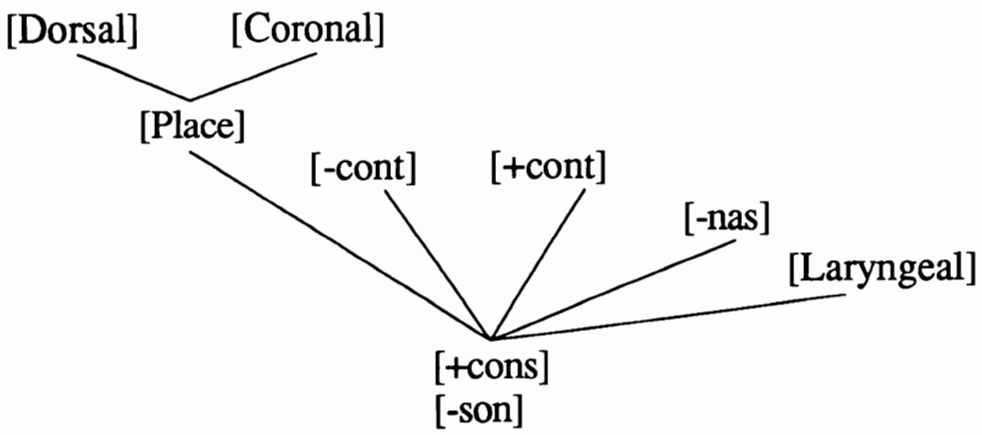


a. $\quad / n d /$

[Coronal]

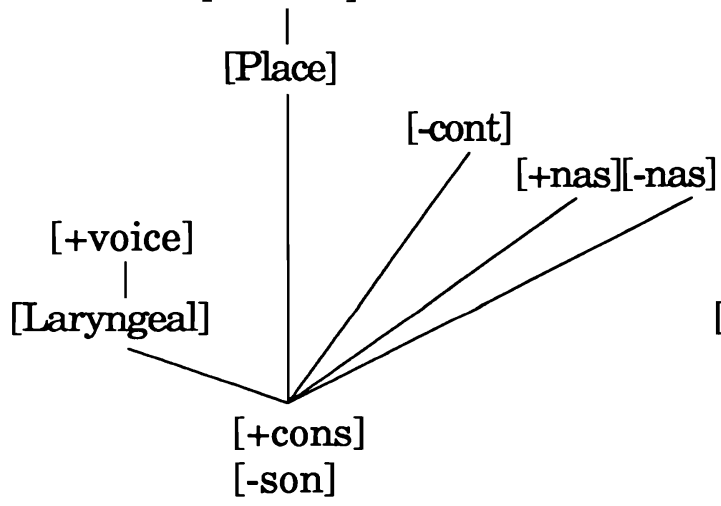

/s/

[Laryngeal]

[Coronal]

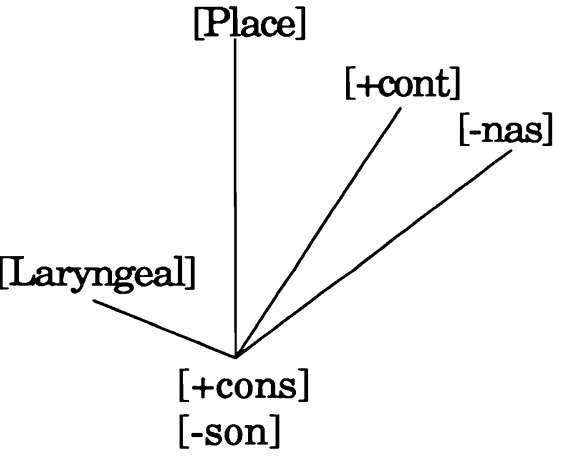

b. Affrication

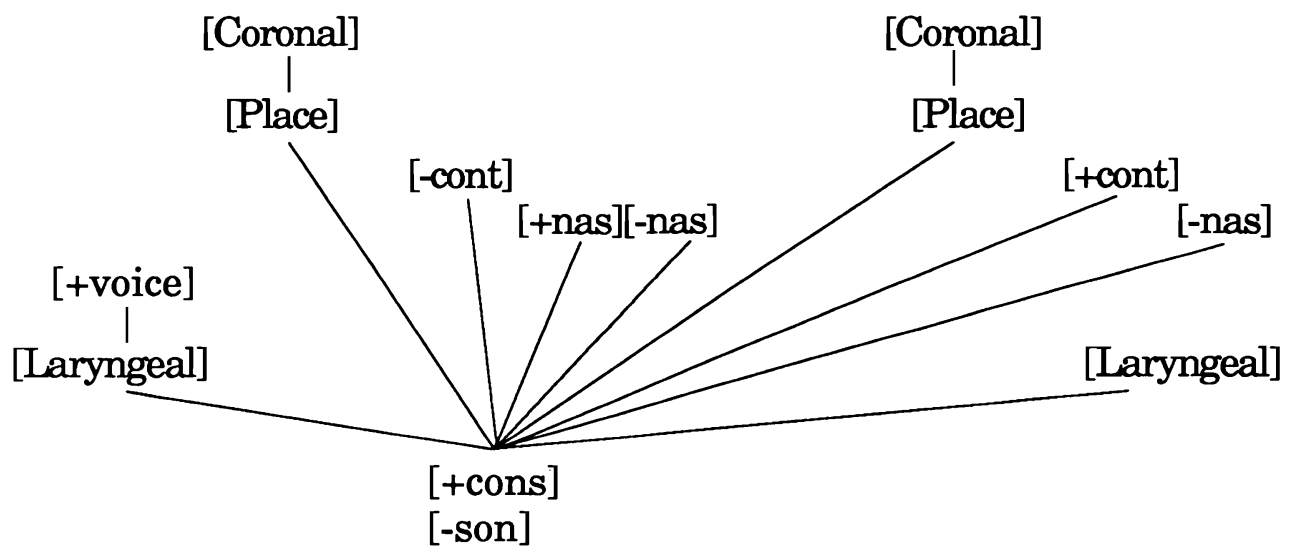


Assuming that the broad generalization is that there are no prenasalized affricates, we can state it either with the filter (30a), or the persistent rule (30b). 20

(30)
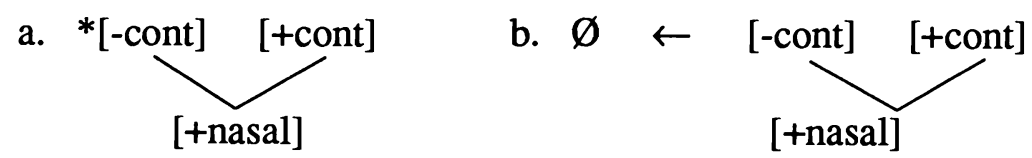

The filter simply says that prenasalized affricates are ill-formed, while the persistent rule (30b) says that they are always converted to prenasalized fricatives. Both would account for the fact that Shona lacks a contrast between prenasalized fricatives and prenasalized affricates.

But once again the causative mutations provide evidence favoring the persistent rule. The relevant alternations involve prenasalized radical-final consonants, as in (31).

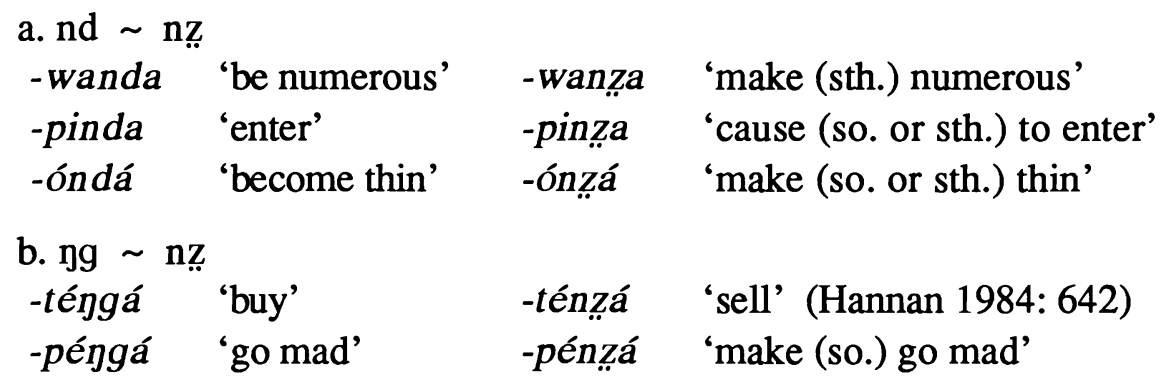

By our hypothesis, the mutated consonants in these cases are derived from a sequence of a prenasalized stop followed by the causative /s/. Assuming the persistent rule (30b), we derive the [nz] in (31a) as follows.

20 I will assume that in a prenasalized segment, specifications for [continuant], [sonorant] and the laryngeal features are interpreted as specifications of the oral portion, not the nasal portion. A simple nasal, for example, is [-continuant], but a prenasalized fricative is [+continuant], and a sequence of [-continuant]-[+continuant] connected to nasal is interpreted as a prenasalized affricate. This interpretation might be language-particular; [+nas] connected to [+cont] could also quite plausibly be the representation of a nasal fricative, and one might wonder if the difference between that and a prenasalized fricative could be attributed to differences in low-level coordination of gestures.

The contrast between prenasalized fricatives and affricates is neutralized in most Bantu languages, usually in favor of the latter. 
wrongly leads us to expect no mutation in this case, since the /s/ would not be fused with the preceding consonant.

Further motivation for the persistent rule (27b) comes from the Class 9/10 mutations (cf. (23) above). When the Class $9 / 10$ marker is juxtaposed with a voiced affricate, the result is not a prenasalized affricate, but a prenasalized fricative. 21

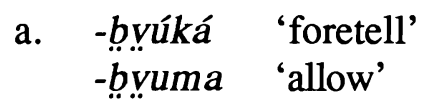

b. mu-ḍambíringwa 'creeper' myúkó 'presentiment (9)'
mvumo 'permission (9)'

nzambíringwa 'fruit of creeper (9)'

The derivation of the mutated consonant in these cases is just as in (32), except that the persistent rule ( $30 \mathrm{~b})$ is fed by Prenasalization, a fusion process analogous to Affrication which creates prenasalized segments from nasal + consonant sequences.

The remaining causative mutations all involve labial consonants (examples from Fortune [1982: 36]).

a. $\mathrm{p} \sim \mathrm{sv}$ -tépá 'be thin' -tésvá 'make thin'

b. $6 \sim$ dzy -reba 'be long' -redzya 'lengthen'

c. $v \sim$ ZY -vává 'be bitter' -vázyá 'make (sth.) bitter' -nóróvá 'be soft, moist' -nórózya 'soften, moisten'

d. $\mathrm{mb} \sim \mathrm{nz} .$. -vimba 'be proud' -vinzya 'make (so.) proud'

These are all the examples of this sort that I know of, so one would not want to base too much on them. But it is interesting that the analysis as it stands would account for all of these alternations except for that in (34a). As an example, I offer the following derivation of the mutated consonant in (34b).

21 Other words show another pattern according to which the Class $9 / 10$ mutation of a voiced affricate is a voiced affricate. This can be expressed with a persistent rule like (30b) except that it deletes the nasal specification instead of the stop specification. 
c. Twin Sisters Convention

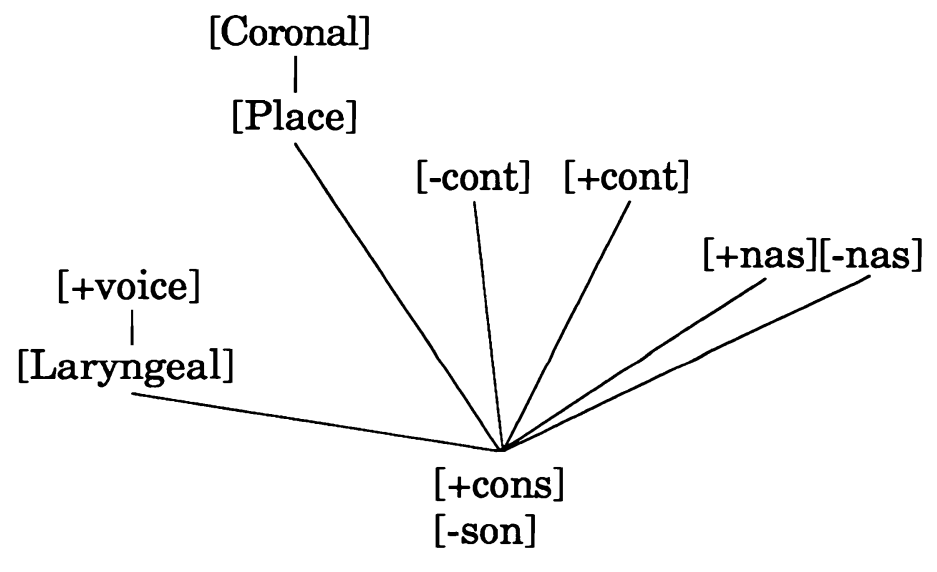

d. Persistent Rule (30b)

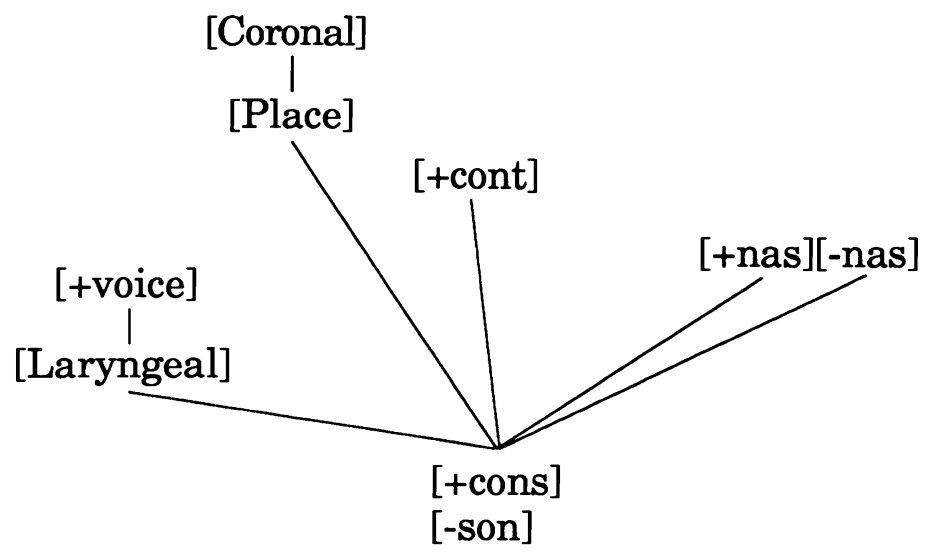

The representation in (32a) is the sequence nd $+s$, and that in (32b) is the result of Affrication. This representation includes the illicit feature combination of a prenasalized affricate, which is eliminated by the persistent rule (30b). Note that the mutated consonant inherits the voicing of the prenasalized stop, because the /s/ lacks any laryngeal specification. Voicing of the mutated consonant is, thus, always determined by the radical consonant, not the affixal /s/. The derivation from $/ \mathrm{ng} /$ to [nz], as in (31b), is the same, but with the additional application of (27b) to remove the dorsal place specification.

The filter makes the wrong predictions here. It predicts that Spirantization will be blocked because it would create an ill-formed prenasalized affricate. It thus 


\section{c. Twin Sisters Convention}

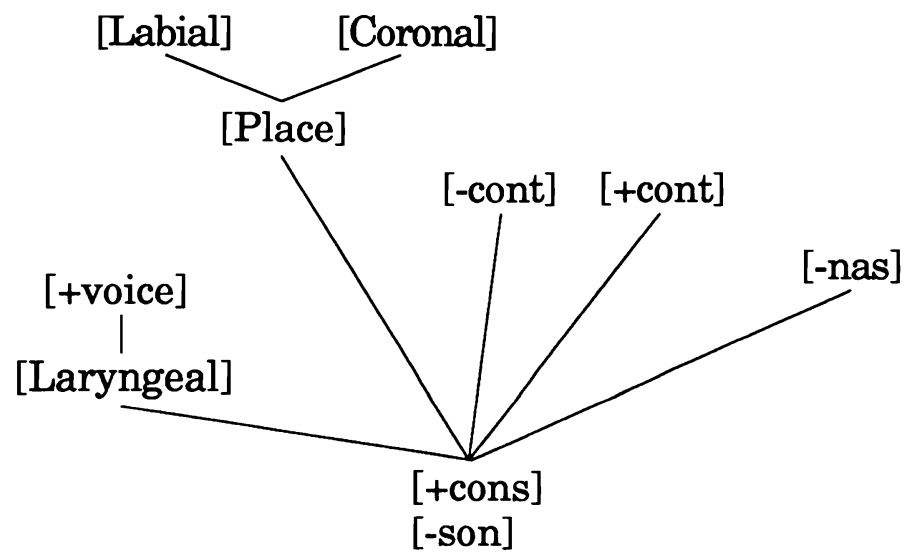

Affrication adds a coronal place of articulation and a continuant manner of articulation to a segment that has a labial stop articulation. But this combination of features is fine in Shona; the result is labiocoronal because it has both labial and coronal place specifications, and it is an affricate because it has both [-cont] and [+cont] specifications. The example (34c) differs in that both of the fused consonants are [+cont] in that case, while (34d) simply involves the additional step of eliminating the resulting prenasalized affricate by rule $(30 \mathrm{~b})$. The example (34a), on the other hand, is anomalous, because we would expect the mutated consonant to be an affricate [tsv], by analogy with (34b).

We have now examined all the alternations associated with the Shona causative mutation. I have argued here that both the productive causative suffix -is- -esand the causative mutations are derived from a single causative suffix /-s- $/$. The vowel in the productive allomorph is due to a general rule of epenthesis that breaks up illicit consonant clusters. The mutations are due to the interaction of Affrication with the various persistent rules governing the Shona continuants. Affrication is optional, and when it doesn't apply, the unsyllabified /s/ triggers epenthesis.

There are a number of advantages to this analysis. First, all the rules involved, except for Affrication itself, are independently motivated. The epenthesis rule is needed anyway for the other extensions, and for the other cases discussed in Section 2. Likewise, there must somewhere in the grammar be a specification of what continuants are allowed in Shona. If we formulate this specification in terms of persistent rules, then we also get the mutation effects by structure preservation.

Second, this account of mutation goes quite a ways toward explaining which consonants have mutated counterparts and which don't. It is notable, for example, that there are no mutated versions of any coronal continuants. If these were fused 
Epenthesis, mutation, and structure preservation in the Shona causative

(35)

a.

/b/

/s/
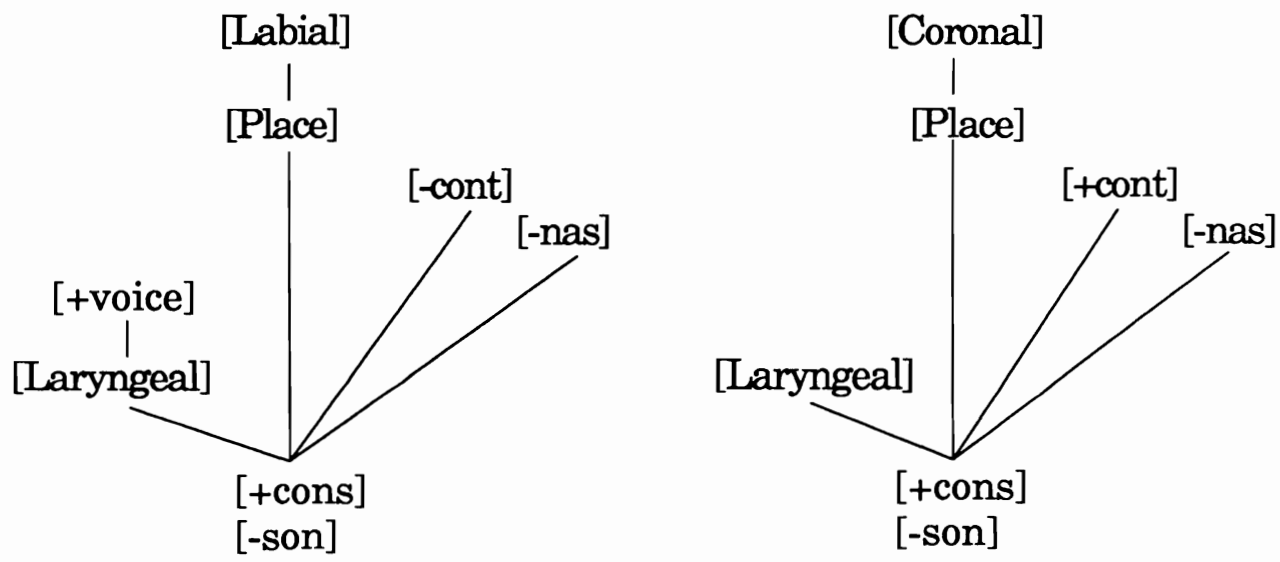

b. Affrication

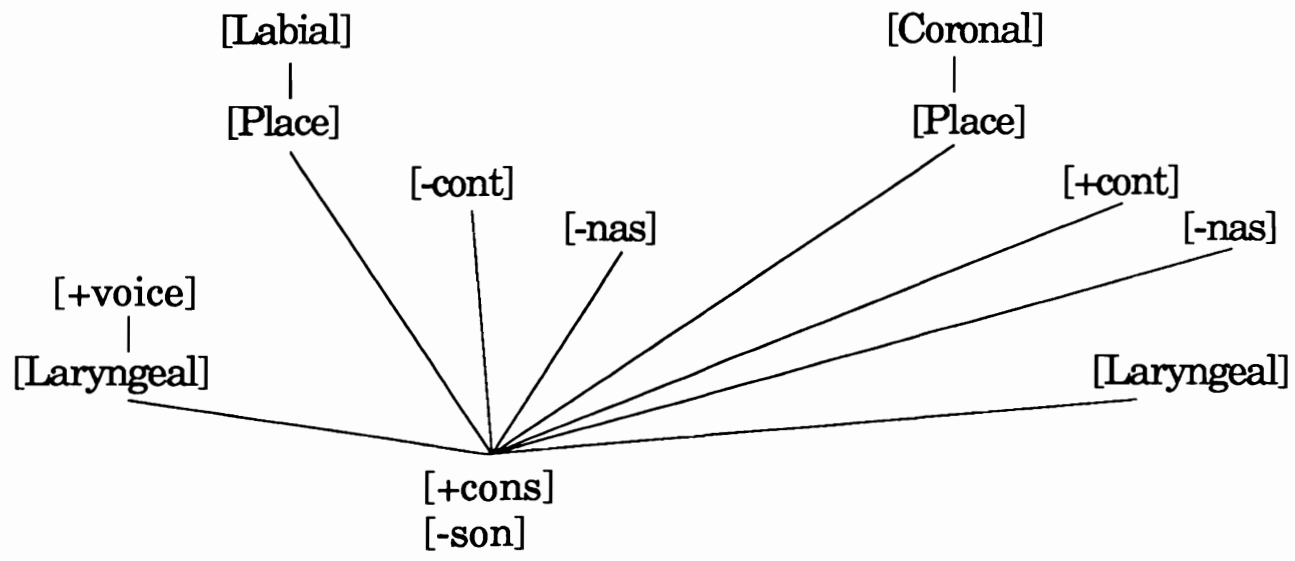


Broselow and Niyondagara propose that the mutation is triggered by a causative marker /i/, which spreads a coronal specification to the preceding consonant. 23 In the case of velars, Broselow and Niyondagara [1990] note that the output of this assimilation would be palatalized velars $\left({ }^{*} \mathrm{k} y,{ }_{\mathrm{g}} \mathrm{y}\right)$, which do not occur in Kirundi. They posit a rule of Dorsal Delinking which delinks the Dorsal node of the consonant, leaving just the Coronal node. This rule is straightforwardly interpretable as a persistent rule; it is indeed very similar in effect to our persistent rule (27b). The causative mutation can then be seen as a simple assimilation operation, the output of which is subjected to active operations expressing feature co-occurrence conditions, as in our analysis of the Shona case.

The Shona causative mutation supports the reconstruction of the mutationinducing causative as $*_{-j}$. The basic Proto-Bantu stop series, for example, remains unchanged in Shona, except before Proto-Bantu *i [Guthrie 1971, vol. 2: 62]. Before $*_{i}$ Shona consistently has coronal continuants, i.e., the segments that now arise in the consonant mutations.

(37) Correspondences before Proto-Bantu *i [Guthrie 1967]

$\begin{array}{lllll}\text { PB } & \text { Shona } & & & \underline{\text { PB }} \text { root } \\ \text { b } & \text { zy } & \text { e.g., -zyạr- } & \text { 'bear (child)' } & \text { *-bịád- } \\ \text { d } & \text { dz } & \text { e.g., -dzzi } & \text { 'root' } & \text { *-dị } \\ \text { g } & \text { z } & \text { e.g., zíná } & \text { 'name' } & \text { *-gína } \\ \text { p } & \text { sv } & \text { e.g., -svik- } & \text { 'arrive' } & \text { *-pìk- } \\ \text { t } & \text { s } & \text { e.g., u-síkú } & \text { 'night' } & \text { *-tịku } \\ \text { k } & \text { ts } & \text { e.g., mu-tsíndo } & \text { 'audible footstep' } & \text { *-kíndo }\end{array}$

The difference between Shona and other Bantu languages such as Kirundi is that in Shona there is no longer any synchronic motivation for positing a high front vocalic or semi-vocalic articulation in the mutation-inducing causative.

I would suggest that the innovation in Shona has to do with the absence in that language of the common Bantu process of palatalization, according to which $\mathrm{CiV}$ $\rightarrow$ CyV. In Shona, there is simply deletion: $\mathrm{CiV} \rightarrow \mathrm{CV}$.

a. nd-a-vérenga

1S-PST-read

'I read (earlier today)' cf. ndi-nó-verejga

1S-HAB-read

'I read'

23 Broselow and Niyondagara assume, following Clements [1976] and Mester and Ito [1989], that front vowels are coronal. 
by Affrication with /s/, they would be unaffected, so there would be no mark of the causative suffix. Given that Affrication is optional, pragmatic considerations will favor the epenthetic version of the causative in these cases. Likewise, a plain nasal cannot be combined with a voiceless fricative such as /s/ in Shona, as is apparent from the Class 9/10 mutations. This then accounts for the fact that no plain nasal has a mutated counterpart. The murmur stops are generally restricted to borrowed radicals, and the mutation never seems to apply to those. There are no cases of mutation with $/ \mathrm{d} /, / \mathrm{g} /$, or $/ \mathrm{h} /$, but these consonants appear so rarely in radical-final position that this would not be a surprising accidental gap.22 That leaves unexplained only the non-participation of the labial continuants.

\section{Diachronic Development}

It is quite common in the Bantu family for a language to have two forms of the causative: one a suffix corresponding to Shona -is-/-es- and the other a mutation. Guthrie [1967] traces the contrast back to Proto-Bantu. Bastin [1986] reconstructs the mutation-inducing suffix as $*_{-j} i$, and the other one as $*_{-j} i c i$, where $i$ is an extra-high (i.e., "tense") high vowel.

The reconstruction of the mutation-inducing suffix is uncontroversial. The original high front articulation is preserved in many languages as a secondary palatalization of some radical-final consonants. Consider, for instance, the following alternations in Kirundi [Broselow and Niyondagara 1991].
Unmutated $\underline{\text { Mutated }}$
Unmutated $\underline{\text { Mutated }}$
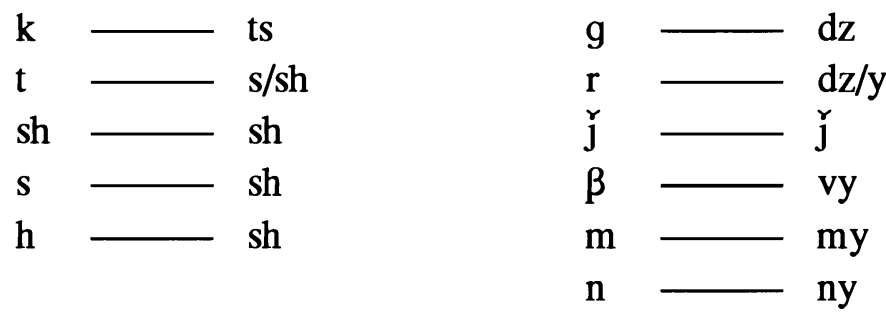

In most cases the mutated consonant differs from the unmutated consonant in having a coronal articulation. In the case of $m, \beta$, and $n$, this is a secondary palatal articulation.

22 I conducted a search of Hannan [1984] for radicals of the form -CVd-a, -CV g̈-a, and -CVĥ-a, since -CVC-a is by far the most common structure for radicals, and most longer forms are constructed by addition of a set of (often lexicalized) suffixes that do not include $d, \ddot{g}$, and $\hat{h}$. In the 757 pages of the Shona-English dictionary, there were only 21 native Zezuru radicals of the form -CVd-a, 11 of the form -CVg̈-a, and none of the form -CVḥ-a (-jahna 'gallop' is borrowed from Nguni). 


\section{References}

Alsina, Alex and Sam Mchombo. 1990. The Syntax of Applicatives in Chichewa: Problems for a Theta-Theoretic Asymmetry. Natural Language and Linguistic Theory 8: 493-506.

Archangeli, Diana and Douglas Pulleyblank. 1986. The Content and Structure of Phonological Representations. Ms., University of Arizona and USC.

Aronoff, Mark. 1976. Word Formation in Generative Grammar. Cambridge: MIT Press.

Bastin, Y. 1986. Les suffixes causatifs dans les langues bantoues. Africana Linguistica 10: 55-145.

Broselow, Ellen and Alice Niyondagara. 1990. Feature Geometry of Kirundi Palatalization. Studies in the Linguistic Sciences 20: 71-88.

Broselow, Ellen and Alice Niyondagara. 1991. Morphological Structure in Kirundi Palatalization: Implications for Feature Geometry. In Francis Katamba (ed.), Studies in Inter-Lacustrine Bantu Phonology. Köln: Afrikanistische Arbeitspapiere 25: 131-155.

Clements, George. 1976. Palatalization: Linking or Assimilation?. In S. Mufwene, C. Walker and S. Steever (eds.), Papers from the 12th Regional Meeting. Chicago: Chicago Linguistics Society, pp. 96-109.

Clements, George and Samuel J. Keyser. 1983. CV Phonology. Cambridge: MIT Press.

Carter, Hazel and George Kahari. 1979. Kuverenga Chishóna, Part II. London: School of Oriental and African Studies.

Doke, Clement. 1931. A Comparative Study of Shona Phonetics. Johannesburg: University of the Witwatersrand Press.

Fivaz, Derek. 1970. Shona Morphophonemics and Morphosyntax. PhD. dissertation. Johannesburg: University of the Witwatersrand.

Fortune, George. 1955. An Analytical Grammar of Shona. London: Longmans.

Fortune, George. 1982. Shona Grammatical Constructions. 2nd revised edition. Harare: Mercury Press. 

b. t-ó-vérejga
1P-EXCL-read
'We are about to read'
cf. ti-nó-verejga
1P-HAB-read
'We read'
c. č-otó 'fireplace (Cl. 7)'
cf. či-ṇu 'thing (Cl. 7)'

The vowel [i] does not alternate with a secondary palatal articulation, as in other Bantu languages, and in fact there are no consonants with secondary palatal articulations. 24

The loss of phonological palatalization and its effects (palatalized consonants and alternations with [i]) removed the motivation in Shona for positing any kind of palatal vowel or glide as the causative marker. ${ }^{25}$ It became simpler at this point to analyze the causative as $-s-$, and this had the further advantage of allowing the two causative markers to be collapsed. The result was the current Shona pattern of causative formation.

\section{Conclusion}

I have argued that both forms of the Shona causative are derived from a single affix of the form $/ \mathrm{s} /$. When affixed to a vowel-final root, as in (11), this affix is realized simply as $/ \mathrm{s} /$. When affixed to a consonant-final root, however, an unsyllabifiable consonant cluster results. This is eliminated either through prosodically-motivated epenthesis or through fusion of the two consonants into one (Affrication).

Consonant mutation results from the interaction of Affrication with structure preservation. When Affrication would create a segment that does not occur in Shona, application of the rule does not simply block. Rather, the ill-formed segment is created and then transformed into something else by persistent rules. If structure preservation is stated in terms of persistent rules, it can capture the relation between the gaps in the segment inventory and the mutation alternations. This analysis therefore supports the position of Myers [1991] that languageparticular restrictions on segment structure are better represented by active operations rather than passive filters. ${ }^{26}$

24 There are sounds that are represented in the standard orthography as ty and dy (e.g. -tya 'fear' and -dya 'eat'). But these are velarized, not palatalized: $t y$ and $d y$ being pronounced [čk], and [jg], respectively. These sounds or sound-sequences don't participate in any alternations in Shona.

25 Here and elsewhere I use the term "palatalization" for any assimilation in the direction of a high frony articulation, whether this is instantiated as coronalization $\left(\mathrm{k} \rightarrow \mathrm{s}\right.$ or $\left.\mathrm{k} \rightarrow \int\right)$ or as the addition of a secondary palatal articulation $\left(\mathrm{k} \rightarrow \mathrm{k}^{\mathrm{y}}\right)$.

26 This article was written and submitted before the advent of Optimality Theory [Prince and Smolensky 1993]. The active structure preservation effects described here can be expressed in that model by having the filters on feature co-occurrence dominating members of the PARSE family of constraints. 
Odden, David. 1981. Problems in Tone Assignment in Shona. PhD dissertation. Urbana: University of Illinois at Champaign-Urbana.

Pongweni, Alec. 1981. A Study of the Spectral Properties of Karanga Stops. Zeitschrift für Phonetik, Sprachwissenschaft und Kommunikationsforschung 34: 699-716.

Pongweni, Alec. 1984. An Acoustic Study of Karanga Fricatives. Zeitschrift für Phonetik, Sprachwissenschaft und Kommunikationsforschung 37, 328-347.

Prince, Alan and Paul Smolensky. 1993. Optimality Theory: Constraint Interaction in Generative Grammar. Technical Report \#2, Rutgers Center for Cognitive Science, Rutgers University.

Rice, Keren. 1987. The Function of Structure Preservation: Derived Environments. In Joyce McDonough and Bernadette Plunkett (eds.), Proceedings of NELS 17. Amherst: Graduate Linguistics Student Association: pp. 501-520.

Sagey, Elizabeth. 1986. The Representation of Features and Relations in NonLinear Phonology. Ph.D. Dissertation, MIT.

Selkirk, Elisabeth. 1981. Epenthesis and Degenerate Syllables in Cairene Arabic. MIT Working Papers in Linguistics 3, 209-232.

Steriade, Donca. 1982. Greek Prosodies and the Nature of Syllabification. Ph.D. Dissertation, MIT.

Steriade, Donca. 1987. Redundant Values. In A. Bosch, B. Need and E. Schiller (eds.), Papers from the 23rd Annual Meeting of the Chicago Linguistics Society. Part Two: Parasession on Autosegmental and Metrical Phonology. Chicago: Chicago Linguistics Society, pp. 339-362.

Traill, A., J. Khumalo and P. Fridjohn. 1987. Depressing facts about Zulu. African Studies 46: 255-275.

Watkins, Mark. 1937. A Grammar of Chichewa. Language Dissertation \#23. Baltimore: Linguistic Society of America.

Department of Linguistics

University of Texas

Austin, Texas 78712
[Received June 22, 1992; revision received September 1, 1993; accepted October 8, 1993] 
Guthrie, Malcolm. 1967-1971. Comparative Bantu. London: Gregg.

Halle, Morris and Jean-Roger Vergnaud. 1979. Metrical Structure in Phonology. Unpublished paper, MIT.

Halle, Morris and Jean-Roger Vergnaud. 1987. An Essay on Stress. Cambridge: MIT Press.

Hannan, M. (ed.). 1984. Standard Shona Dictionary. Revised edition. Harare: The Literature Bureau.

Itô, Junko. 1989. A Prosodic Theory of Epenthesis. Natural Language and Linguistic Theory 7: 217-260.

Kiparsky, Paul. 1973. Elsewhere in Phonology. In Steven Anderson and Paul Kiparsky (eds.), A Festschrift for Morris Halle. New York: Holt, Rinehart and Winston, pp. 93-106.

Kiparsky, Paul. 1981. Vowel Harmony. Unpublished paper, Cambridge: MIT.

Kiparsky, Paul. 1982. Lexical Morphology and Phonology. In Linguistics in the Morning Calm. Hanshin: Seoul, pp. 3-91.

Kiparsky, Paul. 1985. Some Consequences of Lexical Phonology. Phonology Yearbook 2: 83-136.

Lombardi, Linda. 1991. Laryngeal Features and Laryngeal Neutralization. $\mathrm{PhD}$ dissertation. Amherst: University of Massachusetts.

McCarthy, John. 1988. Feature Geometry and Dependency: A Review. Phonetica 45: 84-108.

Maddieson, Ian. 1989. Shona Velarization: Complex Consonants or Complex Onsets?. Paper given at the Annual Meeting of the Linguistic Society of America, Washington, D.C.

Mester, R. Armin and Junko Itô. 1989. Feature Predictability and Underspecification: Palatal Prosody in Japanese Mimetics. Language 65: 258-293.

Myers, Scott. 1987. Tone and the Structure of Words in Shona. New York: Garland Press.

Myers, Scott. 1991. Persistent Rules. Linguistic Inquiry 22: 315-344. 
The book is divided into four sections. Papers in the first section (of which there are five), which is entitled "Conceptual Background", essentially address basic conceptual issues, such as "What is meant by the terms 'Africanism'?"and "What is the substratum and what is its influence?". The second section, comprising eight papers, is devoted to "African Influence and Creole Genesis". The third section, "Defending and Identifying African Substrate Influence", contains twelve papers ranging in content from the Ijo element in Berbice Dutch to the Africanness of counterlanguage among Afro-Americans. The final section, comprising two papers, offers "Some Historiographical Notes". 